\title{
BILIARY STENT A FRIEND TURNED FOE IF FORGOTTEN
}

\begin{tabular}{ll}
$\begin{array}{l}\text { Dr Santosh kumar } \\
\text { singh }\end{array}$ & $\begin{array}{l}\text { Department of general surgery, Motilal Nehru college, prayagraj, Uttar } \\
\text { Pradesh. }\end{array}$ \\
\hline
\end{tabular}

\section{Dr. Jitendra Kumar} Singh

\section{Dr. Devendra kumar shukla}

Dr Ankur dutt tripathi*

ABSTRACT Introduction: The studies recommend replacement or removal of stent at least by 3-6 months after ERCP in order to avoid complications such as occlusion or migration of stent or cholangitis. While it cannot be denied that complications may occur following routine stenting too, presence of a stent in the biliary tree left behind for a long duration is especially fraught with danger since, the stent though crucial in patient management, is undoubtedly a foreign body. Method and material: Plastic stenting through ERCP for CBD obstruction was performed in 288 patients. Patients were divided into 3 groups on basis of duration of presentation from their respective date of ERCP Result: 50 out of 288 patients did not provide contact information at time of registration for ERCP. 28 out of 50 patients who did not provide contact details at time of registration presented $>6$ months after ERCP. 260 patients presented for stent removal within 6 months of stenting of which 05 patients (1.9\%) developed stentolith. 28 patients presented $>6$ months after stent placement of which 26 (92.8\%) developed stentolith. Conclusion: All patients with biliary stent must be informed about the importance of its removal on time and complications of long term endoprosthesis in situ. 'Stent Registry System' should be set up under direct supervision of the surgeon is recommended. Stentolith referred to surgeon are usually impacted or too large to be removed endoscopically mandating open choledocholithotomy.

\section{KEYWORDS : endoscopic retrograde cholangiopancreaticography(ERCP); stentolith, cholangitis; common bile} $\operatorname{duct}(\mathrm{CBD})$ stent.

\section{INTRODUCTION:}

Gall stone disease is responsible for 1.8 million hospital visits and more than 700,000 cholecystectomies per year in the United States. ${ }^{[1]}$ More than 1 in 10 patients (10\% - 18\%) undergoing cholecystectomy for gall stones have concomitant bile duct stones. ${ }^{[2]}$ Established approaches to manage the common bile duct (CBD) stones are, (1) Endoscopic sphincterotomy (EST) and stone extraction can clear the bile duct stones in $85 \%$ to $90 \%$ of patients. ${ }^{[3]}$ (2) Endoscopic retrograde cholangiopancreatography (ERCP) and stone removal with or without stent placement, (3) laparoscopic and (4) open common bile duct exploration. Usual sequence of event for CBD stone management is ERCP guided removal of CBD stones followed by stent placement and cholecystectomy once inflammation subsides and then stent removal within 6 months after ERCP. Biliary stenting is performed either with plastic or metal stents. The mean duration of patency of stent is about 12 months $^{[4,5]}$.

In a study, which investigated foreign body infection in the biliary tract it was found that implants in the biliary tract impaired the local host defense mechanism, resulting in an increased susceptibility to microbial infection and fibrosis. These plastic stents if kept for a prolonged period promote bacterial proliferation, and release of bacterial betaglucuronidase, which results in the precipitation of calcium bilirubinate. Calcium bilirubinate is then aggregated into stones by an anionic glycoprotein ${ }^{[6]}$. The studies recommend replacement or removal of stent at least by 3-6 months in order to avoid complications such as occlusion or migration of stent or cholangitis ${ }^{4}$. This study explores importance of stent registry system and the lack thereof.

\section{METHOD AND MATERIAL:}

Records of 288 patients who underwent ERCP with stent placement between August 2017 to January 2018, at Swaroop
Rani Nehru hospital, Prayagraj, U.P. India were collected during March and April 2019 for the purpose of this study.

\section{The patients were divided in 3 groups:}

1-Group A-Patients who returned for stent removal spontaneously at or before 6 months of their respective ERCP date.

2- Group B-Patients who returned for stent removal after they have been traced by their phone number/address at or before 6 months of their respective ERCP date.

3- Group C- Patients who presented more than 6 months after their respective ERCP date.

\section{INCLUSION CRITERIA:}

1- Stenting done in Moti Lal Nehru Medical College and Swaroop Rani Nehru Hospital, Prayagraj U.P between August 2017 to January 2018.

2- Patients who presented within 16 months of ERCP

3- Biliary stent in situ must be present.

\section{EXCLUSION CRITERIA:}

1- Patient with features of hepatic encephalopathy.

2- Patients with comorbid medical conditions.

3- Patients who never came for follow-up.

\section{OBSERVATION:}

288 patients who underwent ERCP from August 2017 to January 2018 at MLN Medical College and Swaroop Rani Nehru Hospital Prayagraj, UP were studied. Only 82.6\% (238 out of 288) patients provided complete contact details at time of registration.

Table 1: Patients whose records were present

\begin{tabular}{|c|c|c|c|}
\hline & $\begin{array}{c}\text { Total } \\
\text { Number of } \\
\text { patients }\end{array}$ & $\begin{array}{c}\text { Patients whose } \\
\text { records were } \\
\text { present }\end{array}$ & Percentage \\
\hline
\end{tabular}




\begin{tabular}{|c|c|c|c|}
\hline Male+Female & 288 & 238 & $82.6 \%$ \\
\hline Male & 100 & 88 & $88 \%$ \\
\hline Female & 188 & 150 & $79.8 \%$ \\
\hline
\end{tabular}

Table 1 shows 100 males and 88 females underwent ERCP stenting. Of 288 patients, 238 registered their address and phone number. $88 \%$ males and $79.8 \%$ females provided contact information.

Table 2: Patients who returned for removal of stent spontaneously at or before 6 months of ERCP

\begin{tabular}{|c|c|c|c|}
\hline & $\begin{array}{c}\text { Total Number of } \\
\text { patients }\end{array}$ & $\begin{array}{c}\text { Patients who } \\
\text { returned for } \\
\text { removal of stent }\end{array}$ & Percentage \\
\hline & 288 & 182 & $63.2 \%$ \\
\hline Male & 100 & 60 & $60 \%$ \\
\hline Female & 188 & 122 & $64.9 \%$ \\
\hline
\end{tabular}

Table 2 shows $63.2 \%$ (182 out of 288) patients returned at or before 6 months for removal of biliary stent. $60 \%$ males and $64.9 \%$ females followed up without being summoned.

Table 3: Patients who returned at or before 6 months of ERCP after being contacted.

\begin{tabular}{|c|c|c|c|}
\hline & $\begin{array}{c}\text { Total Number of } \\
\text { patients }\end{array}$ & $\begin{array}{c}\text { Patients called for } \\
\text { removal of stent }\end{array}$ & Percentage \\
\hline & 288 & 78 & $27.1 \%$ \\
\hline Males & 100 & 32 & $32 \%$ \\
\hline Females & 188 & 46 & $29.8 \%$ \\
\hline
\end{tabular}

Table 3 shows $27.1 \%$ (78 out of 288 ) patients were traced and called for biliary stent removal. $32 \%$ males and $29.8 \%$ females returned for stent removal after being contacted.

Table 4: Patients presented $>6$ months after ERCP

\begin{tabular}{|c|c|c|c|}
\hline & $\begin{array}{c}\text { Number of } \\
\text { patients }\end{array}$ & $\begin{array}{c}\text { Patients presenting with } \\
\text { cholangitis }>\text { 6 months } \\
\text { after ERCP }\end{array}$ & Percentage \\
\hline Total & 288 & 28 & $9.7 \%$ \\
\hline Males & 100 & 08 & $8 \%$ \\
\hline Females & 188 & 20 & $10.6 \%$ \\
\hline
\end{tabular}

Table 4 shows $9.7 \%$ patients presented after 6 months of stenting $8 \%$ were males and $10.6 \%$ were females. 28 out of 50 patients who did not provide contact details at time of registration presented $>6$ months after ERCP.

Table 5: Patients presenting with stentolith

\begin{tabular}{|c|c|c|c|c|}
\hline $\begin{array}{c}\text { Time of } \\
\text { Presentation }\end{array}$ & $\begin{array}{c}\text { Total } \\
\text { patients }\end{array}$ & $\begin{array}{c}\text { Patient with } \\
\text { stentolith }\end{array}$ & $\begin{array}{c}\text { Patient without } \\
\text { stentolith }\end{array}$ & $\begin{array}{c}\text { p- } \\
\text { value }\end{array}$ \\
\hline$<6$ months & 260 & 05 & 255 & 0.0001 \\
\hline$>6$ months & 28 & 26 & 02 & \\
\hline
\end{tabular}

In table 5: 260 patients presented for stent removal within 6 months of stenting of which 05 patients (1.9\%) developed stentolith. 28 patients presented after 6 months of stent placement of which 26 (92.8\%) developed stentolith

Table 6: Patients presenting with cholangitis

\begin{tabular}{|c|c|}
\hline Variables & No. of patients \\
\hline Mean Age (in years) & 44 \\
\hline Male:Female & $0.4: 1$ \\
\hline Abdominal pain & 28 \\
\hline Fever & 26 \\
\hline Jaundice & 25 \\
\hline Pancreatitis & 0 \\
\hline Internal migration & 5 \\
\hline Stentolith & 31 \\
\hline Without symptoms & 0 \\
\hline WBC count / ml & 18500 \\
\hline Total Bilirubin (mg//dL) & 3.8 \\
\hline ALP (IU/L) & 356 \\
\hline AST (IU/L) & 76 \\
\hline
\end{tabular}

\begin{tabular}{|c|c|}
\hline ALT (IU/L) & 90 \\
\hline Serum Albumin (g/dL) & 2.9 \\
\hline Stricture & 2 \\
\hline
\end{tabular}

Table 6 shows patients with Mean Age (in years) is 44years, Male:Female is 0.4:1. Patients with abdominal pain are 28, fever are 26. Patients with jaundice are 25, but having pancreatitis are none. Patients wih internal migration are 5 and stentolith are 31 . There were no patient without symptoms,. Average WBC counts are $18500 / \mathrm{ml}$ and having average total bilirubin $3.8 \mathrm{mg} / \mathrm{dl}, \mathrm{ALP}$ is $356 \mathrm{IU} / \mathrm{L}, \mathrm{AST}$ is 76 $\mathrm{IU} / \mathrm{L}, \mathrm{ALT}$ is $90 \mathrm{IU} / \mathrm{L}$ and serum albumin $2.9 \mathrm{~g} / \mathrm{l}$. Patients with stricture are 2 .

\section{DISCUSSION:}

In our study CBD stent was placed in 288 patients of which 238 $(82.6 \%)$ patients provided contact information. 88 out of 100 males (88\%) and 150 out of 188 females $(79.8 \%)$ provided contact information. $17.4 \%$ patients did not provide contact information at time of registration for procedure.

A literature review via the PubMed and Google Scholar databases of English language studies published until April 2019 revealed there are many studies about the biliary stents, however there are a few case reports about the forgotten biliary stents. No data was found on compliance with stent registry system among patients and hospital administrations.

Setting up of a computerized 'Stent Registry System' under direct supervision of the surgeon is recommended so that the stents placed for various therapeutic procedures are not forgotten both by the patient as well as the surgeon. There must be a deadline for biliary stents in registry system for each patient ${ }^{[4]}$. All patients with biliary stent must be informed about the importance of its removal on time and complications of long term endoprosthesis in situ. They should be instructed to contact the ERCP unit if symptoms of cholangitis develop. Patient education for timely follow-up and removal of the stents is the key to avoid potentially lethal complications ${ }^{[7]}$

In our study among 288 patients 182 (63.2\%) patients returned for removal of biliary stent spontaneously within 6 months of stenting. $60 \%$ (60 out of 100 ) males and $64.9 \%$ (122 out of 188 ) females returned for follow-up on time of their own accord.

$78(27.1 \%)$ patients were traced and called for biliary stent removal. $32 \%$ (32 out of 100) males and $24.5 \%$ (46 out of 188) females had to be called for stent removal.

$28(9.7 \%)$ out of 288 presented after 6 months of stenting, 8 (8\%) were males and $20(10.6 \%)$ were females.

A forgotten stent in the CBD may remain in situ for years without any complication ${ }^{[8]}$. Recurrent cholangitis is the most common complication after biliary stentimg which predisposes patient to further risk of secondary sclerosing cholangitis, biliary cirrhosis, potentially fatal icterouremigenic cholangitis, internal stent migration and pancreatitis. Colonic perforation due to biliary stent dislocation and migration to the rectosigmoid colon has also been reported ${ }^{[9]}$. Rarely, a retained stent may act as a nidus for stone formation around it, which is known as "stentolith" ${ }^{\prime[7]}$. Out of 260 patients who returned for stent removal within 6 months of ERCP 4 (1.5\%) developed stentolith.

Out of 28 patients who presented $>6$ months after stent placement 26 (92.8\%) developed stentolith.

$6 \%$ (6 out of 100) males developed stentolith and $12.8 \%$ (24 out of 188) female patients developed stentolith.

In our study all patients who were referred to surgery with stentolith were cases of impacted stentolith or stentolith too 
big for endoscopic removal which made open choledocholithotomy imperative.

\section{CONCLUSION}

In conclusion, endoscopic placement of the endoprosthesis is a simple and safe method for short-term decompression of the biliary system, but after insertion of endoprosthesis, all patients should be informed to be having biliary stents and the possibility of complications related to long-term endoprosthesis placement and must be requested to contact to ERCP unit if symptoms suggestive of cholangitis appear. We recommend all ERCP units maintain a stent registry system under direct supervision of the doctor so that the stents placed for various therapeutic procedures are not forgotten both by the patient as well as the physician. There should be a deadline for biliary stents in registry system for each patient. In our study female patients have greater percentage of negligence in recording their details and therefore at greater risk of developing stentolith. In biliary stents staying more than 6 months. Common complication of forgotten stent in situ are cholangitis, obstructive jaundice, stentolith and internal stent migration. As the stent may get impacted within the stone, an endoscopic procedure may not be successful in such cases, especially with a large stentolith, mandating surgical removal. A simple age old procedure of scrupulous record keeping in ERCP patients can save a patient from life threatening complications and avoidable surgery. There was no conflict of interest between the authors.

\section{REFERENCES}

1. Everhart JE, Ruhl CE. Burden of digestive diseases in the United States. Part III: liver, biliary tract, and pancreas. Gastroenterology 2009;136:1134-44.

2. Martin DJl, Vernon DR, Toouli J. Surgical versus endoscopic treatment of bile duct stones. Cochrane Database Syst Rev. 2006 Apr 19;(2):CD003327

3. Chopra KB, Peters RA, O'Toole PA, Williams SGJ, Gimson AES, Lombard MG, Westaby D. Randomized study of endoscopic biliary endo $\neg$ prosthesis versus duct clearance for bile duct stones in high-risk patients. Lancet 1996; 348: 791-93

4. Mehmet Odabasi, Cem Arslan, Sami Akbulut, Haci Hasan Abuoglu, Erkan Ozkan, Mehmet Kamil Yidiz et al. Long term effects of forgotten biliary stents: A case series and Literature Review. International Journal of Clinical and Experimental Medicine.2014;7(8):2045-2052

5. Ang TL, Fock KM, Teo EK, Chua TS, Tan J. An audit of outcome of long term biliary stenting in treatment of CBD stones in a general hospital; J. Gastroenterology. 2006.Aug;41(8):765-771.

6. Yu JL, Andersson R, Wang LQ, Ljungh A, Bengmark S. Experimental foreignbody infection in the biliary tract in rats. Scand J Gastroenterol. 1995;30:478-83. [PubMed] [Google Scholar]

7. Bansal VK, Misra MC, Bhowate P, Kumar S et al. Laparoscopic Management of Common Bile Duct 'Stentolith'.Trop Gastroenterology. 2009 AprJun;30(2):95-96.

8. Bajbouj M, Treiber M, Ludwig L et al. Forgotten biliary endoprosthesis. "Follow up" after 10 years. Endoscopy 2008; 40: E221

9. Namdar T, Raffel AM, Topp SA, Namdar L, Alldinger I, Schmitt M, Knoefel WT, Eisenberger CF. Complications and treatment of migrated biliary endoprostheses: A review of the literature. World J Gastroenterol 2007; 13(40): 5397-5399

10. Dobronte Z, Patai A. Palliative treatment of large bile duct stones by endoscopic implantation of endoprosthesis in high risk patients. Orv Hetil. 1996; 137:461-4. [PubMed] [Google Scholar] 